\title{
Social Capital, Joint Responsibility Systems, And Empowerment Of Women In Msmes : A Conceptual Framework
}

\author{
Anni Yudiastuti ${ }^{1.2}$, Heri Pratikto ${ }^{3}$, Sopiah ${ }^{4}$ \\ ${ }^{1}$ Faculty of Economics and Business, Widya Karya Catholic University of Malang, Indonesia \\ ${ }^{2,3,4}$ Faculty of Economics and Business, State University of Malang, Indonesia \\ * Corresponding author: \\ Email: Anniyudiastuti.1904139@students.um.ac.id
}

\begin{abstract}
.
Empowering women, especially in entrepreneurship, is often faced with limited accessibility, especially in meeting capital through loans at formal financial institutions and structural constraints in their environment. Women's cooperatives are a bridge to overcome the problem of women's entrepreneurial capital to increase their business, because basically woman have potential in its business activities. Social capital that has elements of Trust, Network and norms attached to women's personalities will be a guarantee in obtaining loans with a joint responsibility system. The opportunity to develop a business through social capital and joint responsibility has an impact on opening up opportunities to empower micro, small and medium entreprise (MSMEs) business actors to further increase their business and continue to be in a sustainable entrepreneurial position.Sustainable Entrepreneurship for female entrepreneurs offers women professional development and limited flexibility to balance work and family commitments.

Keyword: Social Capital, Tanggung Renteng (Joint Responsibility System) Empowerment Of Women In MSMEs.
\end{abstract}

\section{INTRODUCTION}

Women in Indonesia are currently considered unable to make a significant contribution to developing micro, small and medium enterprises (MSMEs). In fact, it is often considered as a group that is vulnerable to continuation in entrepreneurship. Even though women's participation is increasing in technical and entrepreneurial work in Taiwan, it is less significant because many women still take on traditional roles and identities in technical workplaces (Leung Wing-Fai, 2018). Dili et al. (2013) stated that in this world gender inequality is often encountered, especially in developing countries, where many women face limitations in their freedom. Female MSME actors in Indonesia in 2019 , recorded $50 \%$ of the total 65,465,497 MSMEs. A fairly large number (https://www.kemenkopukm.go.id/data-umkm). Based on these data, then pincreasing women's capacity in developing entrepreneurship is an important strategy to increase women's roles and opportunities in improving their economy.

In general, development scientists consider women to have an important role in development. But reality shows that women globally are poorer than men. They also have less access to health, education and other forms of freedom. In addition to the main responsibility of women is to raise children, and with the resources they have, they bear the responsibility to break the chain of poverty which is inherited from generation to generation. Therefore a community must empower and invest resources for women to produce significant development impacts (Todaro \& Smith, 2013). Lubis \& Saputra (2015) argue that developing countries in Asia including Indonesia should maximize their main/key sectors, to takeadvantage of the resources at their disposal.Research which is conducted In Bangladesh, India, Indonesia, and South Africa, it was found that there are obstacles for women in entrepreneurship, namely; (1) Laws, customs, traditions, culture and religion (2) marital status (3) heavy housework (4) limited education, knowledge and information (5) limited funds as capital and access to credit (6) adequate institutional network inadequate (Ahamad \& Moudud-UI-Hug, 2013; Bhardwaj, 2008; Bruni, Gherrardi \& Poggio, 2004; Derera, Chitakunye \& O'Naill, 
2014; Ganesan, Kaur \& Maheshwari, 2002; Sharma, 2013; Tambunan, 2008 ; Tambunan, 2009).These constraints lead to a tendency for women to choose business fields that do not require high skills and large capital, simple technology and easy to manage.

The main obstacle faced by women in starting or continuing their business in order to increase their income is access to capital. Micro-enterprises, which are mainly run by women, find it difficult to get access to credit from formal financial institutions. Organizations that are considered relevant for efforts to assist women in entrepreneurship, which are usually categorized as micro-entrepreneurs, are through the Women's Cooperative (Kopwan).Julia Newton-Howes, CEO of Investing in Women, an institution formed by the Australian Government to promote the economic empowerment of women in Southeast Asia in a seminar entitled "Scaling Up Women Entrepreneurs" In Jakarta in 2019 provided support in capacity building for MSMEs owned or had an impact on women. "Women in Indonesia are motivated to be economically independent, both as workers and entrepreneurs. We have to start looking at why the system is getting in the way of them in business development."Cooperatives is a financial institution that runs its business in the as a business institutionat a time learning institution for its members. As a business institution, cooperatives must be able to maintain and develop their assets which will ultimately improve the quality of service to members, and as a learning institution, cooperatives must be able to educate their members to be independent so that they can improve welfare.

Women's cooperatives, which are currently growing rapidly, are now able to bridge the two functions of these institutions, cooperatives Indonesian women through joint responsibility system that is a system which contains the spirit of "heavy is the same and light is the same as carried" and the point is togetherness. Joint responsibility is a system that divides responsibilities evenly, applying the concept of collectivity, from designing programs to overcoming problems encountered (Indiyon, 2006). The advantage of this system is that everyone participates in thinking, working, and monitoring. Responsibilities are divided equally so that all have the right to get access to information on business developments and the results of the business in question.Empowering women in entrepreneurship is often faced with limited accessibility, especially in meeting capital through loans at formal financial institutions. Social capital as a philosophy of social capital values consisting of trust, networks and norms is considered capable of supporting the "right" system of joint responsibility. This limitation of capital acquisition from the economic and non-economic side is the target of the implementation of the joint responsibility system, which aims to fulfill capital as well as education and coaching.

The existence of women's cooperatives can be illustrated from the progress that has been made by two major kopwans in Java, namely; Setia Bhakti Wanita Cooperative (KSBW) in Surabaya and Women's Cooperative "Setia Budi Wanita" Poor East Java. The success of the two women's cooperatives is supported by the joint responsibility system in managing revolving funds. Success the achieved advertising has prompted the State Ministry of Cooperatives and SMEs to replicate the joint responsibility system to 30 groups in 30 provinces in Indonesia by providing a revolving fund of Rp. 225 million or Rp. 7.5 million per group.Tanggung renteng or joint responsibility system born and spearheaded by the founder of Women's surgery "Setia Budi Wanita" poor East Java. Evidence of achievements achieved by Kopwan "Setia Budi Wanita" among others Award as a cooperative that has the highest philosophy in East Java Province (2013). achievements at the national level as the best entrepreneurship driving cooperative (2011), and included in the 100 large cooperatives in Indonesia on rating 79(2015). One of ten cooperatives in Indonesia that has received ISO 9001:2008 certification (2016). This achievement and success shows commitment Women's Cooperative "Setia Budi Wanita" East Java in increasing the participation and empowerment of women to be able to be independent and become active and productive MSME actors. This article provide a literature review aims to make a study of the role of social capital in system joint responsibility as a means empowerment female MSME actors for get a loan without collateral, education, Skills and construction. Empowerment These women entrepreneurs are expected to become the fundamental basis in realizing sustainable women entrepreneurs. 


\section{METHOD}

Article this use method and study qualitative which done through study conceptual based on review literature. Aim from discussion this is for knowing role social capital and its implementation in the joint responsibility system and its role in empowering women in sustainable entrepreneurship Results review literature analyzed with use method content analysis.

Conceptual Framework

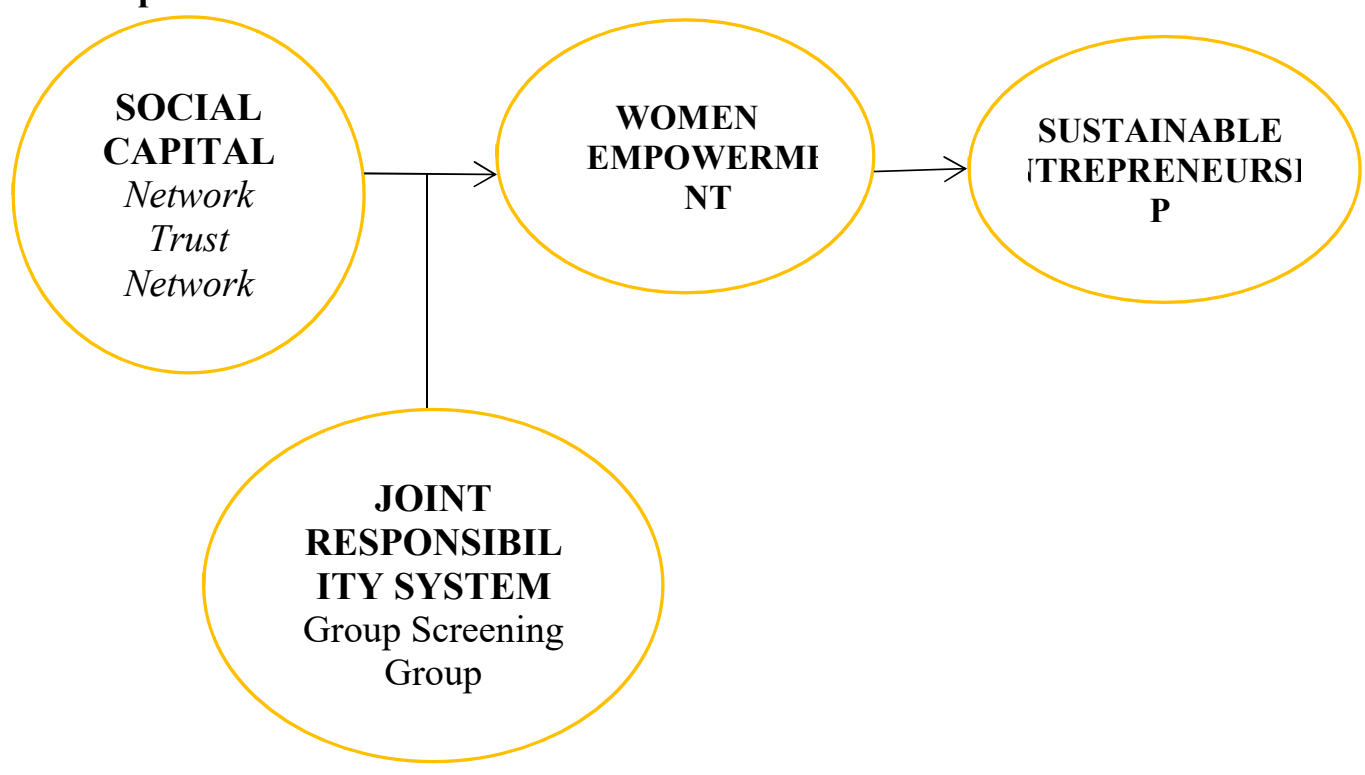

\section{LITERATURE REVIEW \\ Social Capital}

The concept of social capital is based on the idea that it is impossible for community members to individually overcome the various problems they face. There is a need for togetherness and good cooperation from all interested community members to overcome these problems. Social capital is not capital in the usual sense such as wealth or money, but rather has a figurative meaning, but is a real asset or capital that is important in social life.Social capital, defined as trust, norms, and networks that enable people to coordinate actions and achieve their goals (Laurie et al., 2005). The concept of social capital came under the spotlight in the late 1980s and attracted research interest thereafter. The scientific study of social capital is relatively new, but the growth of literature on this topic is enormous. Despite the past literature, there is no single and universal definition of social capital.

Social capital theory has developed a concept starting from Hanifan and developed byBourdieu(1980), Coleman (1988; 1990), Fukuyama (1995), Granovetter (1985; 1995), Putnam (1993; 2000) and apply to various social settings such as family interactions, geography, economic development, business performance, product innovation, entrepreneurship, supply chain management and other related fields of study. This concept has developed in various disciplines such as sociology, anthropology, politics, economics and entrepreneurship in the study of SMEs and EO (Alguezaui \& Filieri, 2010; Salehuddin, 2009).Fukuyama in Bhandari and Yasunobu (2009) emphasizes the qualities in social relationships (interpersonal trust, shared norms and understanding, etc.), which enable people to get along with others, and help to develop modes of behavior. Coleman (1988), Cox (1995), Putnam (2000),Laurie et al., 2005) argued that there are 3 important elements that exist in social capital or social capital, the first is trust, the second is a network, and the third is a norm. Trust is an important element in social capital which is the glue for lasting relationships in community groups. By maintaining a trust, people can work together effectively. Trust, norms and social networks are core concepts in social capital (Coleman, 1988; Putnam, 1993, 2000; Fukuyama, 1995, 1999, 2001 in Lawang, 2004). 


\section{Tanggung Renteng (Joint Responsibility) System}

Tanggung Renteng (joint liabilities) and severally is shared responsibility among members in a group for all obligations to cooperatives on the basis of openness and mutual trust (Supriyanto, 2011). If in one group there are things that deviate or do not meet the requirements then the consequences are borne by all members in the group.Joint responsibility comes from the word responsibility which means to bear, guarantee, state the availability to pay someone else's debt if that person does not keep his promise. While the word jointly means, series, strands. Joint responsibility is defined as shared responsibility among members in a group for all obligations on the basis of openness and mutual trust. The values contained in the joint responsibility system (sistem tanggung renteng) are:

1. Family and cooperation.

2. Openness and courage to express opinions.

3. Instilling discipline, responsibility and self-respect as well as self-confidence to members.

4. Indirectly creating a leadership cadre among members.

LP4 Trisakti East Java (2020) stated that the joint responsibility system aims to improve behavior to be more positive, develop human character, understand rights and obligations as group members and educate members. In essence: improving human quality through interaction between humans in various forms of activity.Gunawan (2003) and Mulyadi (2000) stated that the joint responsibility system is a risk management system in an organization that is realized by sharing responsibilities to all group members in a proportional and tiered manner. The system of equal distribution of responsibilities for the whole group or some members of the cooperative for the obligations of a member to the cooperative. Shared responsibility has become the main innovation that is responsible for the rapid growth of microfinance institutions because of its ability to overcome adverse selection and moral hazard problems in the credit market, especially when providing credit to the poor according to (Xavier and Karlan, 2006).

\section{Empowerment Concept}

Empowerment refers to the word "empowerment" which is an effort to actualize one's potential or an effort to provide the community to determine their own potential so that it can be developed (LP4, 2020). Empowerment is also meant to give power. Women's empowerment has two objectives, first, to release the shackles of poverty and backwardness. Second, strengthening the position of the layers of society in the power structure. Both must be done and become the target of empowerment efforts (Kartasasmita, 1996).Akomolafe (2006) argues that women's empowerment is the development of women's mental and physical capacities, strengths and skills to do something meaningful in their social environment, so that they gain social recognition and are able to improve their economic status. The purpose of economic empowerment for women is to improve the socio-economic status of women by creating an economic culture that contains knowledge about the role of women, empowering them with various economic efforts and increasing women's emancipation from poverty.

\section{RESULTS AND DISCUSSION}

\section{The Role of Social Capital in Cooperatives with Joint Responsibility System}

The research of Chloupkova et al. (2003) explained that social capital has a significant influence on the cooperative movement in Denmark and Poland. In this study, data is presented that participation in civic action in Denmark is twice as high as in Poland, and the level of confidence in Denmark (73.9\%) is higher than in Poland (20.1\%). The cooperative movement in Poland is not well developed, in contrast to Denmark because in Poland social capital was eroded by the communist regime in power there. A similar statement was made by Faedlulloh (2015) which states that the right organization in describing social capital is a cooperative. Social capital has an important role in the cooperative movement and very closely related to the joint responsibility system which is currently widely applied by most women's cooperatives in Indonesia. Women's cooperatives have distinctive characteristics that are different from cooperatives in generally require a different approach to development strategy. This can not be separated from the characteristics of its

http://ijstm.inarah.co.id 
members in the domination of housewives causing its own advantages compared to other cooperatives.Women have characteristics and are able to play a role in managing the household and developing the family economy.The intensity of the meeting is an important factor causing the slow development of kopwan (Hatneny, 2017). In East Java, especially in the city of Malang, the Women's Cooperative holds the potential for power to the economic area.Joint responsibility is used as social security created based on the values that develop in society, namely togetherness, mutual help and trust among community members. This is a system of mutual cooperation and togetherness and the value of mutual responsibility to each member.

Control and reminding each other will bring up a sense of responsibility from each member to the existence of himself and his group. The correct application of the joint responsibility system will foster a rational and responsible mindset, because when applying for a loan, members realize that the funds borrowed belong to all members of the cooperative. So if the obligation is ignored, it means that it is detrimental to all members. The togetherness of the members is really built so that each can support each other. The system of joint responsibility has become a spirit and is one of the main factors for the advancement of women's cooperatives.Coleman (1988) states that as long as a person is involved in social networks and synergizes their strengths, they directly or indirectly increase the strength of the network. On the other hand, by being an active part of a network, one will gain additional strength from the network.Social capital integrated in the joint responsibility system, because build trust between members in the group. Implementation social capital facilities convenience accessibility member especially to get a loan Start up Capital from the Cooperative, although this also has an impact on the risk of joint responsibility that must be borne by members.

The implementation of the joint responsibility system includes joint responsibility in the decision-making process, joint responsibility in financial matters (savings and profit management), joint responsibility in dealing with business risks, and joint responsibility in carrying out organizational burdens, especially regarding the future of cooperatives. Social capital which includes elements: Trust, Network and Norm is an intangible asset which is an actual and potential resources. Trust can be used to assess good intentions in acting and behaving in groups. The joint responsibility system is based on the trust value of other members to make a selection to be able to join the group or the process of getting a loan. network is embodied in apattern relationships that prospective members have built or had with members who have already joined the group. The relationship can be in the form of a strong bond,which is formed based on friendship or kinship. Most of the prospective members already have close relationships with members who have joined the group. This network that is built can eventually become a bridge for prospective members to enter the group. Networks play a role in the process of joining groups, permitting loan applications, and as social and moral security in the joint responsibility system.Norm as an element in social capital according to Coleman (1988) is something that determine what is good and what is bad. Then the norm is expressed in a formal or informal language known as a policy Coleman (1988).so that everyone who has the norm must be aware of the existence and content of the policy. These norms do not only apply in a large scope as a member of the Cooperative but also in the group scope. Within the scope of the norm or rule group can be applied differ from one group to another. This is in accordance with the agreement or the results of the deliberation carried out in the group. Norms play a major role in reducing the risk of joint responsibility, because norms are parts that have been mutually agreed upon.

\section{The Role of Social Capital in Empowering Women Entrepreneurs of SMEs}

Empowerment of women as MSME actors should be directed at development of the mental and physical capacity, strength and skills of women to do something meaningful in their social environment, so that they gain social recognition and are able to improve their economic status. For this reason, the intervention of the Government and the community is needed to support women's empowerment to the expected goals. The community through related institutions has a role in empowerment which is provided in the form of active participation, one of which is through funding programs. This participation can be carried out by cooperatives, especially women's cooperatives, which struggle to increase the role of women in a 
more professional manner. Social capital and the system of joint responsibility that are the soul of women's cooperatives are able to bridge obstacles and solutions for women's empowerment through women's cooperatives. Social capital which consists of: trust, network and norms, supports women who are members of women's cooperatives to easily obtain information, participate and carry out mutually beneficial cooperation so that members have the ability to utilize their resources.Tata \& Prasad (2008) suggest that social capital provides an opportunity for an entrepreneur to have a network in accessing information and resources for business.

The results of this study are in accordance with the results of research by Idris and Agbim (2015) which show that social capital has a significant effect on the economic empowerment of women entrepreneurs in Nigeria. The role of social capital in women's empowerment can be seen in the growth of relations between fellow members, the establishment of networks and organizations between cooperatives, the establishment of activities that build a spirit of independence through communication forums, business meetings and knowledge sharing. Trusts are actually useful for obtaining assistance or loans from cooperatives without collateral for their business capital when formal assistance from banks is very limited for women. Loans or unsecured loans to women as members of cooperatives give their members the ability or strength to start or continue their businesses, thereby creating women's independence. Putnam (1993) suggests that trust is a key component of social capital.Norms as social capital also play a role in empowering women. Norms that are held with high commitment become a strong basis in every social transaction process and help make social affairs more efficient, so it will be easier for members to get loans to increase their power to become more productive. independent.

The results of this study are in accordance with the results of research by Liang et al. If members are able to run their business well (high productivity), their income will increase and potentially increase their welfare. Arrow (1999) shows that if one does not violate the norm, transactional costs will not exist. On the other hand, if someone violates the norms it will cause losses and thus reduce productivity.Puspito's research (2016) in the Kuantan Brotherhood found that the existence of social capital in the community is one of the main components in moving togetherness, solidarity and mutual trust and mutual benefit to achieve common goals. Supported by Pranadji (2006) strengthening social capital has proven to empower rural communities in managing dry land agroecosystems. This is in line with the research of La Porta et al. (1997) which shows that trust has a significant effect on public participation and GDP growth. Trust promotes cooperation, especially in large organizations. The opportunity to develop a business through social capital and joint responsibility has an impact on opening up opportunities to empower women entrepreneurs to further increase their business and continue to be in a sustainable entrepreneurial position. Sustainable Entrepreneurship for female entrepreneurs offers women professional development and limited flexibility to balance work and family commitments.

\section{CONCLUSION}

Social capital consisting of trust, network, and norm has positive and negative roles in empowering women entrepreneurs of MSMEs in women's cooperatives with a joint responsibility system, especially in loan accessibility, education, skills and coaching. The positive role of social capital is indicated by: the ease of being able to join groups of joint responsibility and obtaining group permission to apply for loans without collateral as business capital, obtaining information, creating mutually beneficial cooperation or partnerships, while the negative role is indicated by: high risk on the repayment of debts and the use of names in the application of loans to the Cooperative.

The empowerment of women is manifested in the ability to utilize the resources they have. Opening business opportunities and access to marketing, as well as increasing income from the businesses occupied.Women's cooperatives in Indonesia are considered capable of assisting the government in overcoming national problems such as: reducing unemployment, improving health, improving education and overcoming gender problems. Women's cooperatives are also a forum for women to improve the family economy, self-actualization for women. Women's empowerment is marked by the status of women, no longer just housewives but also as professional and flexible business actors in micro-enterprises.

http://ijstm.inarah.co.id 


\section{REFERENCE}

[1] Abdussalam, OI, Fuadah, J., \& Alias, MH (2013). Determinants of Women's Empowerment and Its Impact on Poverty Reduction: The Case of Kwara State, Nigeria (Pilot Study). Asian Journal of Social Sciences \& Humanities, 2(4), 342-347.

[2] Ahamad, I., \& Moudud-UI-Hug, S. (2013). Women entrepreneurship in Bangladesh challenges and prospects. International Journal of Innovative Research and Development, 2(7), 41-48.

[3] Akomolafe, CO (2006). Open and Distance Learning as a Women Empowerment Mechanism in Nigeria. Educational Foundations and Management. Received fromhttp://pcf4.dec.uwi.edu

[4] Anam, C. (2016). 99 Cooperatives in Malang City Immediately Freeze. Retrieved from industri.bisnis.com.

[5] Bhandari, H. and Yasunobu, K. (2009) What is social capital: A comprehensive review of the concept. Asian Journal of Social Science, 37, 480-510. doi:10.1163/156853109X436847.

[6] Bhardwaj, G., Parashar, I., Pandey, B., \& Sahu, P. (2008). Women Entrepreneurs in India: Opportunities and Challenges.http://www.chimc.in/Volume2.1/Volume2Issue1/ February 5, 2014.

[7] Bruni, A., Gherrardi, S., \& Poggio, B. (2004). Entrepreneur-mentality, gender and the study of women entrepreneurs. Journal of Organizational Change Management, 17(3), 256-268.

[8] Cahyat, A., Gonner, C., \& Haug M. (2007). Assessing Household Poverty and Welfare: An Example Guide from Kutai Barat, Indonesia. Bogor: Center for International Forestry Research.

[9] Chambers, R. (2013). Rural Development: Prioritizing the Last. New York: Routledge.

[10] Chloupkova, J., Svendsen, GLH, \& Svendsen, GT (2003). Building and Destroying Social Capital: The Case of the Cooperative Movement in Denmark and Poland. Agriculture and Human Values, 20(3), 241-252.

[11] Chow, WS \& Chan, LS (2008). Social networks, social trust and shared goals in organizational knowledge sharing, Information \& Management, 45(7), 458-465.

[12] Coleman, JS (1988). Social Capital in the Creation of Human Resources. American Journal of Sociology: Supplements, Organizations and Institutions: Sociological and Economic Approaches to the Analysis of Social Structure, 94, 95-120.

[13] Derera, F., Chitakunye, P., \& O'Neill, C. (2014). Entrepreneurs in south africa the impact of gender on start-up capital: A case of women. Journal of Entrepreneurship, 23(1), 95-114. http://dx.doi.org/10.1177/0971355713513355

[14] Dilli, S., Rijpma, A., \& Carmichael, S. (2013). Development versus Heritage: The Relative Role of Development and Historical Heritage in Achieving Gender Equality. CESifo Working Paper, No. 4411

[15] Dili, S. (2015). Historical Perspective on Gender Inequality and Development in the World Economy, c. 18502000. Dissertation. Utrecht University Warehouse.

[16] Faedlulloh, D. (2015). Social Capital in the Cooperative Movement. Indonesian Journal of Public Administration, 1(1), 5-19.

[17] Fukuyama, Francis (1995) Trust: The Social Virtues and the Creation of Prosperity. New York: The Free Press.

[18] Ganesan, R., Kaur, D., \& Maheshwari, R. (2002). Women entrepreneurs: Problems and prospects. Journal of Entrepreneurship, 11(75), 75-93. http://dx.doi. org/10.1177/097135570201100105.

[19] Hatneny, Aleria I. "Women's Cooperatives and Women's Empowerment in Developing a People's Economy in Malang City."Journal of Food Security, vol. 1, no. 2, 2017.

[20] Ghozali, I. (2008). Structural Equation Modeling: Alternative Method with Partial Least Square. Edition Two. Semarang: Diponegoro University Publishing Agency.

[21] Hall JK, Daneke, GA and Lenox, MJ (2010), "Sustainable development and entrepreneurship: Past contributions and future directions", Journal of Business Venturing, Vol. 25 No. 5, pp. 439-448.

[22] Idris, AJ, \& Agbim, KC (2015). Effect of Social Capital on Poverty Reduction: A Study of Women Entrepreneurs in the State of Nasarawa, Nigeria. JORIND, 13(1), 208-222.

[23] Kartasasmita, G. (1996). Development for People: Combining Growth and Equity. Jakarta: CIDESINDO.

[24] Leung Wing Fai (2018). Digital Entrepreneurship, Gender and Intersectionality Palgrave Macmillan; 1 st Edition. 2019 edition.

[25] Liang, Q., Huang, Z., Lu, H., \& Wang, X. (2015). Social Capital, Member Participation, and Cooperative Performance: Evidence from Zhejiang China. International Journal of Food and Agribusiness Management Review, 18(1), 49-78.

[26] La Porta, R., Lopez-de-Silanes, F., Shleifer, A., \& Vishny, RW (1997). Trust in big organizations. American Economic Review, Papers and Proceedings, 87(2), 333-338. 
[27] Laurie, Nina, Robert Andolina and Sarah Radcliffe (2005) 'Ethnodevelopment: Social Movements, Creating Experts and Professionalising Indigenous Knowledge in Ecuador', Antipodes 37(3): 470-96.

[28] Lubis, RF, \& Saputra, PMA (2015). The Middle-Income Traps: Is There a Way Out for Asian Countries? Indonesian Journal of Economics and Business, 30(3), 273-287.

[29] Naicker, V., Le Roux, S., Bruwer, J. and Bruwer, JP, 2017. Knowledge Sharing as a ValueAdding Initiative for South African SMME Sustainability: A Literature Review. Expert Journal of Business and Management, 5(2), pp.51-60.

[30] Olomola, USA (2002). Social Capital, Microfinance Group Performance and Poverty Implications in Nigeria. Ibadan: Nigerian Institute of Social and Economic Research. Received fromhttp://citeseerx.ist.psu.edu.

[31] Arrow, KJ (1999). Social Capital Observation. In Partha D., and Ismail, S. (eds), Social Capital: A Multifaceted Perspective. Washington DC: World Bank.

[32] Pranadji, Tri., 2007, Rural Community Empowerment Model for Dry Land Agroecosystem Management (Study on Strengthening Social Capital in Upstream Villages in the Watershed Ex the Bangun Desa Project, Gunung Kidul Regency and Ex Dry Land Agriculture Project, Boyolali Regency, Journal of Agro-Economic Vol. 24 No.2.

[33] Puspito, Hendro. 2016. Sociological Study of Social Capital in the Kuantan Singingi Perjasing Javanese Brotherhood Association. JOM FISIP Journal. Vo. 3. No. 1. P 1-15

[34] Putnam, R. (1993). Prosperous Society: Social Capital and Community Life.

[35] Received fromhttps://www.prospect.org.

[36] Rajivan, A. (2001). Microcredit and Women's Empowerment: A Case Study of EMS (SHARE Microfinance Ltd.). United Nations Development Program (UNDP). Drink. Taken from https://www.microfinancegateway.org.

[37] Saskara, IAN, Pudjihardjo, M., Maskie, G., \& Suman, A. (2012). Review of Economic and Non-Economic Perspectives of Balinese Women Working in the Public Sector: A Study of Role Conflicts. Journal of Management Applications, 10(3), 542-552.

[38] Sasongko, SS (2009). Gender Concepts and Theories. Second Printing. Jakarta: Center for Gender Training and Quality Improvement for Women, BKKBN.

[39] Supriyanto, Gatot. 2011. Joint Liability System Application. Kopwan Setia Bhakti Women East Java.

[40] Sen, A. (1999). Development as Freedom. New York: Anchor Book.

[41] Sharma, P. (2013). Women entrepreneurship development in India. Global Journal of Management and Business Studies, 3(4), 371-376

[42] Tambunan, T. (2008). Women entrepreneurs in micro, small \& medium entreprises: Some evidence from asia developing countries. University of New South Wales at ADFA, 1-28.

[43] Tambunan, T. (2009). Women entrepreneurs in Indonesia: Their main constraints and reasons. Journal of Asia Entrepreneurship and Sustainability, 5(3), 37-51.

[44] Tata, J., \& Prasad, S. (2008). Social capital, collaborative exchange and microenterprise performance: Gender roles. International Journal of Entrepreneurship and Small Business, 5(3/4), 373-385.

[45] Todaro, MP (2001). Economic Development in the Third World. Translated by Haris Munandar. Edition 7. Jakarta: Erlangga.

[46] Todaro, MP, \& Smith, SC (2013). Economic Development. Volume I Edition 11. Jakarta: Erlan

[47] Valentinov, V. (2004). Towards Social Capital Theory of Cooperative Organizations. Journal of Cooperative Studies, 37(3), 5-20.

[48] Woolcock, M., \& Narayan, D. (2000). Implications of Social Capital for Development Theory, Research and Policy. World Bank Research Observer, 12(2), 225-249.

[49] World Bank. (2000). World Development Report 2000/2001: Attacking Poverty.

[50] Obtained from https://siteresources.worldbank.org.

[51] World Bank. (2011). World Development Report 2012: Gender Equality and Development. Retrieved from http://siteresources.worldbank.org.

[52] LP4 Trisakti East Java, Cooperatives and the Joint Responsibility System in Facing the Challenges of the Times, Setia Budi Cooperative Malang East Java, 2020. 